\title{
Relativita sociálnej spravodlivosti ako základného princípu sociálnej politiky štátu
}

\author{
Relativity of social justice as a basic principle \\ of social policy of the state
}

\author{
Oskár Tóth \\ https://doi.org/10.33542/VSS2020-2-07
}

\begin{abstract}
Each state of Western civilization, which is identified by the boundaries of three basic subsystem - the system approach and value legacy of ancient Greece, Christianity, Christian social teaching, modern and postmodern political ideologies, implements a certain model of social policy. Social justice is one of the main principles of social policy. It is a natural requirement of society, which aims to ensure the good of society on behalf of individuals and various social groups. Social justice is the subjects of research by scientists and theorists in the fields of philosophy, sociology, law, economics, and political science. Its essence is relative and change in the time and space. The main goal of the paper is to identify common intersections of individual scientific disciplines with a view to social justice. Presented contribution is a part of solution of Project VEGA 1/0290/20 - Sociálna spravodlivost' a starobné dôchodkové sporenie $v$ Slovenskej republike.
\end{abstract}

Keywords: State, Justice, Social Justice, Social Policy

\section{Úvod}

Skúmanie sociálnej spravodlivosti predstavuje vždy aktuálnu tému vedeckého bádania, ktorý výrazným spôsobom ovplyvňuje dejinný vývoj človeka a spoločnosti. Náročnost' teoretického výskumu vychádza zo širokej a bohatej škály rôznych prístupov, definícií, charakteristík a argumentov, z ktorých niektoré môžu protirečit' alebo až popierat' existenciu a možnost' sociálnej spravodlivosti. Rôznorodost' l'udskej existencie neumožňuje skúmat' sociálnu spravodlivost' izolovane ako samostatný koncept, ale vo vzt’ahu s inými fenoménmi. Sociálna spravodlivost' predstavuje sociálnu hodnotu, ktorá sa často zužuje na spravodlivé prerozdelenie dobier, príležitostí, prostriedkov zabezpečenia medzi jednotlivcov užšej skupiny $\checkmark$ rámci celej spoločnosti. Otázka sociálnej spravodlivosti nie je obmedzená len na individuálne hladisko, pretože hodnota sociálnej spravodlivosti je relevantná takmer vo všetkých oblastiach 
sociálnych vzt’ahov a inštitúcií. Z toho dôvodu je nevyhnutné venovat' mimoriadnu pozornost' identifikácii spravodlivosti, sociálnej spravodlivosti v teoretickej reflexii, ale tiež aj jej aplikáciu $\checkmark$ praxi. Nie je možné unifikovat' a absolutizovat' jej podobu, chápanie a používanie, napriek tomu je nevyhnutné vždy istým spôsobom reflektovat' jeho uplatňovanie v praktickom živote a rešpektovat' mocenské a legislatívne vymedzenie. Existuje široké spektrum aplikácie sociálnej spravodlivosti v živote človeka, jednotlivých sociálnych skupín, ale aj spoločnosti ako celku.

Zvýšená pozornost' vzt’ahu medzi spravodlivost'ou a sociálnou spravodlivostou sa dostáva do popredia najmä v súvislosti $s$ jeho využitím $v$ kontexte sociálnej politiky. $\vee$ jej učebniciach sa čoraz častejšie používa pojem sociálna spravodlivost' (niekedy však aj pojem spravodlivost' bez kvalifikácie), aj ked' je interpretovaný výrazne odlišne. Existuje vel'a prístupov, a teda aj definícií spravodlivosti, ale aj celá škála klasifikácií a typológií, ktoré sa ich autori snažili rozlíšit'. V literatúre možno rozlišovat' distributívnu, procedurálnu, alokačnú spravodlivost' a d'alšie iné (Konečný 2019).

\section{Rôznotvárnost' sociálnej spravodlivosti z diferentného pohl'adu vedných disciplín}

Filozofia a vedné disciplíny vzniknuté v neskorších etapách vývoja, sa pokúšajú objasnit' zaužívanie „objektívnej“ spravodlivosti a sociálnej spravodlivosti v spoločnosti (Földesi 1983). Jednotlivé spoločenské vedy sa stali nezávislými vednými disciplínami v rôznom čase v závislosti od spoločenských potrieb a intelektuálneho rozvoja éry (Andorka 1997). Prirodzené rozdiely v skúmaní vznikali, vznikajú z dôvodu rozdielnych metód, predmetu a jazyka skúmania vedných disciplín. $\vee$ neposlednom rade sa vedné disciplíny líšia aj svojím obrazom človeka (Andorka 2003).

Predstavitelia filozofie od Aristotela až po Rawlsa jednohlasne dospeli k záveru, že spoločenská vzájomnost' je jedným z pilierov sociálnej spravodlivosti. Vzájomnost' vytvára iba možnost' sociálnej spravodlivosti, ale nemusí automaticky viest' $k$ jej vytvoreniu. Reciprocita sa stáva v spoločnosti základom sociálnej spravodlivosti, ak existuje určitý stupeň vzájomnej závislosti medzi skutočnými alebo vnímanými výkonmi a z nich vyplývajúcimi benefitmi, v zmysle ktorých možno tento pomer považovat' za spravodlivý (Ludassy 1989). Porovnávanie nemá zmysel ak neexistuje žiadna sociálna nerovnost', ktorú by mohli ludia pocit’ovat' ako nespravodlivú, pretože spoločnost' nie je spravodlivá ani nespravodlivá (Földesi 1983).

Ako východiskový stav možno použit' citát Protagorasa: „Človek je mierou všetkých vecí", znamená to, že aj mierou l'udskej spravodlivosti je človek - spoločenská realizácia človeka; predstavuje hnaciu silu a základ ludského konania. Z hl'adiska západnej civilizácie prvý dôsledný prehl'ad spravodlivosti v starovekom grécku podali Platón a Aristoteles (Ludassy 1989). 
U Platóna spravodlivost' predstavuje cnost' šátu (štát v tomto prípade znamená spoločnost'), čo je rovnaké ako št'astie. V nadväznosti na právnu vedu zastával názor, spravodlivý je ten človek, ktorý dodržuje zákony. Preto sa právo na spravodlivost' začleňovalo do verejného myslenia a neskôr sa toto právo odvodilo z pojmu spravodlivosti. (Kis 2000).

V Aristotelových myšlienkach a tézach je spravodlivost' povýšená na najvyššiu cnost', v ktorej sú zahrnuté všetky cnosti. Spravodlivost' predstavuje to, čo každý musí dostat' na čo je oprávnený, na čo má nárok, a čo si zaslúži. Vyslovená téza platí pre individuálne konanie, spoločenskú činnost', vrátane spoločenských inštitúcií, štátu, politického alebo právneho poriadku. Záverom uvedeného myšlienkového pochodu je spravodlivost' ako najväčšie dobro v štáte, ktorá prispieva celku (Samu 2008). Tieto zákonitosti tvoria základ pre posudzovanie jednotlivých prípadov: „Spravodlivost’ predstavuje cnost', výsledkom ktorej každý dostane jemu patriace, v zmysle zákonov.“. Dôraz je kladený na spravodlivé prerozdelenie. Uvedený typ spravodlivosti, nazývaný distribučná spravodlivost', zahŕňa uznanie zásluh a uspokojovanie potrieb a zmiernenie materiálnych nerovností v spoločnosti. Aristoteles pokračoval vo svojich myšlienkach; následne hovorí o vyrovnávaco-opravnej, korektívnej spravodlivosti, ktorej podstatou je zhodné porovnanie konatela škody a poškodeného a vyrovnanie nerovnosti $v$ týchto aspektoch.

Tým boli položené základy všeobecného vnímania spravodlivosti ako aj jej rôznych foriem, to znamená aj sociálnej spravodlivosti v západnej civilizácii. Rozvojom spoločnosti, poznania a vznikom samostatných vedných disciplín, každá začína skúmat' spravodlivost', sociálnu spravodlivost' prierezovo vlastným jazykom, metódou, metodikou a predmetom skúmania.

Obraz človeka z pohladu sociológie je tvorený ako homo sociologus. Snahou človeka by malo byt' komfortné správanie vo vzt'ahu k spoločenským normám, ktoré sú na neho kladené, tým pádom spoločnost' bude schopná fungovat' ak si jej členovia tieto normy príjmu za svoje, vyznačuje sa to predvídatelným správaním pre ostatných členov spoločnosti. Disciplinované správanie môže obmedzit' bezprostredné uspokojovanie potrieb ich oneskorením, úpravou, niekedy za účelom spoločenského uznania, niekedy za účelom budúcich cielov. Spoločenský život vyžaduje od jednotlivcov vynaloženie úsilia. Normy a pravidlá môžu byt' často prísne a tvrdé, ich dodržiavanie okamžite neponúka spoločenské uznanie a práve preto najjednoduchším spôsobom na ich dodržiavanie je ak ich jednotlivci vnímajú ako prostriedky na dosiahnutie ich ciel'ov.

Sociológia pri skúmaní spoločnosti sa vo väčšej miere zameriava na koncept sociálnej nerovnosti v porovnaní sociálnej spravodlivosti, čo však nepredpokladá, že tieto poznatky vedy neumožnia spoznanie skúmaného fenoménu. Neodmyslitel'ne existujú rozdiely medzi lud'mi, ale nie všetky rozdiely môžeme považovat' za sociálne nerovnosti a nie všetky sociálne nerovnosti sa dajú považovat' za nerovnosti z ludského hladiska. Na základe názoru Blaua sú 
l'udské nerovnosti takými rozdielmi medzi lud'mi, ktoré uspokojujú ich potreby na rôznych úrovniach , a umožňujú jednotlivcom uspokojovat' ich individuálne potreby počas celého života. Tieto nerovnosti ako uvádza Blau môžu ale aj nemusia mat' charakter spoločenských nerovností (Angelusz 2004). V rámci odbornej verejnosti sú autori, ktorý považujú spoločenské nerovnosti medzi jednotlivcami a skupinami v kultúrach spoločnosti za dôležité a oceňujú ich (Andorka 2003). Druhá skupina autorov zastáva názor, ktorý k spoločenským, sociálnym nerovnostiam pristupujú ako k rozdielom medzi l'ud'mi, ktoré ovplyvňuje ich život, najmä ich práva alebo príležitosti, odmeny alebo privilégiá, ktorými disponujú. Farkas charakterizuje spoločenské nerovnosti ako nerovnosti, ktoré existujú v sociálnych predpokladoch na zabezpečenie potrieb jednotlivcov alebo skupín v spoločnosti.

Prítomnost' sociálnych nerovností v spoločnosti naznačuje iba relatívny cielový bod, v ktorom môžu byt' spoločenské javy ako sociálna spravodlivost' dôsledne identifikovaná ako pojem aj ako činnost'. Podstatu sociálnej spravodlivosti nemožno zúžit' smerom k jednému, aj ked' $\mathrm{k}$ jej vel'mi dôležitému, určujúcemu faktoru - sociálnej nerovnosti, pretože jej pochopenie je výsledkom zložitého skúmania viacerých prvkov, ktoré ich integrujú. Determinujúca náročnost' tohto fenoménu má významnú úlohu v skutočnosti, že rôznorodý pohl'ad na sociálnu spravodlivost' sa nevyjadruje iba $v$ tom, že niektorí jednotlivci spoločnosti považujú sociálne nerovnosti za spravodlivé alebo nespravodlivé. Sociálna spravodlivost' sa prejavuje aj v rôznych doplñajúcich a protichodných tvrdeniach členov spoločnosti (Andorka 2003).

Osobitnú kategóriu teórií tvorí vztah vednej disciplíny práva a spravodlivosti (Pokol 1991). Právna teória rozlišuje vymedzenie spravodlivosti medzi právnym pozitivizmom a prirodzeným právom. Pretrváva tendencia nadradenosti hmotného práva vo vzt'ahu spravodlivosti a iných právnych hodnôt. So zretel'om na zásady prirodzeného práva, právne požiadavky, právne hodnoty vo svojej previazanosti, do popredia kladie spravodlivost' pri tvorbe právnych noriem. Na druhej strane právny pozitivizmus zdôrazňuje stabilitu, právny poriadok, právnu istotu s ciel'om presadzovania právnych požiadaviek akým je aj spravodlivost' (Hart 1995). Skutočne silným môže byt' právo, ktoré je spravodlivé, prinajmenšom do tej miery, do akej sa knedokonalému človeku môže priblížit' myšlienka spravodlivosti a vždy viac či menej dokonalé právo. Spravodlivost' predstavuje možnost', nie nevyhnutnú kvalitu spoločenského poriadku, ktorým sa riadia ludské vzt'ahy; to znamená, že človek je práve vtedy spravodlivý, ked' sa riadi spoločenskými normami, ktoré sú $v$ tom čase a priestore spoločnostou považované za spravodlivé (Kis 2000).

Rovnost' v práve sa nie vždy zhoduje s tým, čo je všeobecne morálne správne, a táto podoba rovnosti sa uvádza najmä $v$ dvoch situáciách spoločenského života. Na jednej strane, ked' sa zaoberáme individuálnym správaním, ako sú medzi spoločenské skupiny rozdel'ované určité práva, povinnosti a bremená v spoločnosti. $\vee$ uvedenom prípade sa spravodlivost' a nespravodlivost' vymedzuje z pohl'adu spoločenskej skupiny. Na strane druhej stojí právne 
chápanie rovnosti v situáciách ujmy, škôd a nárokov odškodnenia (Samu 2008). Spravodlivost' a rovnost' sa využíva na vynášanie súdov aj pri iných spoločenských udalostiach. Skutočne porozumiet' odvodeným použitiam pojmu spravodlivosti, je možné ak už spoločnost' pozná primárny pojem spravodlivost' z pohl'adu distribúcie a nápravy (Visegrády 2001). Všeobecnou zásadou, ktorá spočíva v týchto rozličných použitiach pojmu spravodlivost', je to že jednotlivci majú nárok na určitú formu relatívnej rovnosti alebo nerovnosti. Predstavuje to stav, ked'sa pri rozdelení práv a povinností aj dynamike spoločnosti musí rešpektovat', a ak sa poruší musí sa napravit'. Spravodlivost' je preto komplexný pojem. Z toho dôvodu za spravodlivost' pokladá udržiavanie alebo obnovenie rovnováhy alebo proporcie, a preto sa používa v oblasti práva myšlienka „s podobnými prípadmi sa zaobchádza rovnako“, neodôvodnené rozdiely nie sú prístupné (Samu 2008).

Ekonomická teória stavia spoločnost' pred rozhodnutie, aké statky vyrábat', ako ich vyrábat' a kto bude mat' z nich úžitok. Ekonómovia sú prinajmenšom tak rozdelení na základe svojej politickej filozofie ako zvyšok spoločnosti. Konzervatívny ekonómovia sú zástancami toho, aby obmedzili štátnu intervenciu a zmiernili, ukončili programy prerozdel'ovania zdrojov a prijmov. Ekonómovia neodmietajúci štátne zásahy sú rovnako zanietení požiadavkou na zníženie chudoby a nezamestnanosti prostredníctvom makroekonomických prostriedkov. Ekonómia ako veda sa nemôže rozhodnút', ktoré politické postavenie je správne a ktoré je nesprávne (Mellár 2015).

Ekonomický pohl'ad zdôrazňuje postavenie hospodárskej politiky štátu, ktorá musí byt' založená na účinnosti a tým maximalizovat' blahobyt spoločnosti. Predstava, že spoločnost' musí čelit' zásadnému kompromisu medzi sociálnou spravodlivost'ou a hospodárskym rastom, predstavuje spojovací článok medzi ekonomickou teóriou a diskusiou spoločnosti. Základným predpokladom teoretikov je že nadmerné sociálne úsilie na podporu spravodlivého rozdelenia príjmu alebo bohatstva narúša fungovanie trhových mechanizmov a môže viest' $k$ brzdeniu v trhovej ekonomike, a teda spôsobuje náklady vo forme straty príjmu a budúceho hospodárskeho rastu. Uvedenú myšlienku sformuloval americký ekonóm Arthur Okun, pred štvrt'storočím, ktorý napísal, že nerovnost' odráža systém odmien a trestov za povzbudenie úsilia jednotlivcov. Snaha o efektívnost' nevyhnutne vytvára nerovnosti a spoločnost' je konfrontovaná s kompromisom medzi rovnost'ou a účinnost'ou (Deane 1997).

Čast' predstavitel'ov ekonomickej teórie argumentuje, že klúčovým mechanizmom prerozdel'ovania na zmiernenie sociálnych nerovností sú dane a transfery, ktoré znamenajú značné náklady na úkor efektívnosti. Z tohto hladiska sa dá usúdit', že dane využívané na redistribúciu a transfery znižujú u jednotlivcov motiváciu pracovat', šetrit' čoho následkom v budúcnosti môže byt' „stuhnutie“ trhu práce, zníženie výkonu na pracovisku a pokles investícií. Klúčové mechanizmy na vyrovnanie trhových príjmov, ako napríklad kolektívne vyjednávanie a legislatívne normy zamestnávanie, sa klasickou ekonómiou tiež všeobecne 
považujú za ekonomicky neefektívne, pretože vedú k „deformáciám“ miezd (Mátyás 2004). Otázka kompromisov je kriticky dôležitá pre progresívnych obhajcov hospodárskej a sociálnej politiky, ktorí chcú dosiahnut' viac rovnakých príležitostí a rozdelenie prijmov, ako len čisto mechanizmami vol'ného trhu. Tí, ktorí sa zasadzujú za redistribúciu príjmov v spoločnosti v záujme sociálnej spravodlivosti alebo ktorí sú za spravodlivejšie rozdelenie trhových prijmov, sa budú musiet' skonfrontovat' s oponentmi, ktorí sa budú snažit' dokázat', že redistribúcia vedie $\mathrm{k}$ celkovej strate príjmov; v najväčšej miere $v$ prípade ak ich názorový oponenti dokážu preukázat', že domácnosti s nízkymi príjmami sú $v$ každom prípade $v$ lepšom postavení v spoločnosti s vysokou mierou nerovnosti, ako s vysokými príjmami. Otázka, kto má úžitok z kompromisu „spravodlivost' pre efektívnost" sa často prehliada (Bodai 2001).

Makroekonómia a mikroekonómia nie sú dve ekonomiky, ale dve štruktúrne časti jedného celku národného hospodárstva. Makroekonomická politika sa pritom zaoberá predovšetkým otázkami makroekonomickej rovnováhy a efektívneho využívania zdrojov, smerujúcim k zabezpečeniu efektívnej realizácie základných celospoločenských cielov (Konečný 2019).

Ekonómia, predovšetkým hospodárska politika má na sociálnu politiku významný vplyv. Výsledky hospodárskej politiky sú materiálnou základňou pre sociálno-politické rozhodnutia. Sociálna politika „spotrebováva“ produkované statky. Previazanost' sociálnej a hospodárskej politiky je podmienený aj hodnotovo. Záleží na spoločnosti kolko z vytvoreného bohatstva $v$ danom momente venuje na sociálno-politické opatrenia (Geffert 2014).

V ludskej spoločnosti moc má tendenciu neustále sa inštitucionalizovat', čiže spájat' sa s nejakou inštitúciou, štátom, národom či organizáciou. Vtedy moc prestáva byt' už len l'udským vzt’ahom a stáva sa inštitúciou (napr. štátom), ktorá je spojená s právom, zákonmi a inými pomocnými prostriedkami moci. L'udia potom už ovládajú jeden druhého nie iba na základe svojej osobnej prevahy, vlastností, sily, ekonomického potenciálu, ale aj na základe tých atribútov moci, ktoré sú vlastné príslušnej inštitúcii alebo organizácii (štát, úrad, škola, politická strana, spolok, korporácia, atd'.) (Bihari, Pokol 2009).

Pri úvahách o t’ažiskovom probléme nášho záujmu, ktorým je porozumenie sociálnej spravodlivosti, musíme vychádzat' zo vzájomného vzt’ahu politológie a etiky ako dvoch rovnocenných vedných disciplín. Politológia sa zaoberá, makroštrukturálnymi spoločenskými vzt’ahmi (z hladiska politickej moci a riadiacich manažérskych procesov $v$ politike). $V$ rámci týchto spoločenských vzt’ahov na makroúrovni majú nezastupitel'né miesto morálne vzt’ahy, ktoré skúma ako vedná disciplína etika. Morálne vzt’ahy bezprostredne súvisia s uznávaním, hierarchizáciou a uplatňovaním hodnôt $v$ každej l'udskej spoločnosti, v každom období jej historického vývoja, lebo z nich vychádza existujúca morálka danej society. Fundamentálny význam majú z tohto hladiska univerzálne mravné normy a pravidlá, ktoré sú fundamentálnou mravnou bázou vo všetkých svetových civilizáciách a kultúrach. Pokial' uvažujeme o mieste, 
úlohe a postavení etiky v politickom procese, nemôžeme abstrahovat' od takých podstatných morálnych kategórií, ako sú dobro a zlo, politická sloboda a politická zodpovednost', základné hodnoty, sloboda vol'by, svedomie a čest', či politické ciele a prostriedky politického konania (Voegelin 2014).

Samotný výkon politickej moci sa realizuje v konkrétnom politickom systéme určitého šátu. $Z$ tohto aspektu politický systém možno definovat' aj ako určitý priestor, $v$ ktorom funguje a uplatňuje sa politická moc. Historicky sa politická moc chápala ako istý "strážca", ktorý mal zaist'ovat' nerušené fungovanie a rozvoj (Bayer 2001).

V modernej spoločnosti vstupuje človek do verejného života nielen ako občan štátu, ale aj ako člen rôznych politických i nepolitických organizácií (záujmových združení, spolkov, odbory, politické strany, atd'), a preto takáto rôznorodost' (pluralita) záujmov vytvára $\vee$ spoločnosti reálny základ ústavného a politického systému pluralistickej demokracie. Cielom pluralistickej demokracie je, aby sa vytvoril inštitucionálny rámec pre optimálnu realizáciu záujmov ludí, ale aby sa pritom rešpektovali jednak predstavy väčšiny, ochrana záujmov menšiny a minimalizovali sa obmedzenia každého jednotlivca (Paczolay 1996). Občan sa má stat' nie pasívnym objektom, ale najmä aktívnym subjektom štátno-politického života. Demokratický systém a jeho politické inštitúcie (štátne orgány, politické subjekty, záujmové skupiny) by mali vediet' primerane reagovat' na požiadavky, ktoré nastoluje "občianska spoločnost", pretože $v$ inom prípade nie je zaručená stabilita tohto systému. Dôležitou súčastou pluralistických spoločností sú ich základné hodnoty, medzi ktoré sa najčastejšie radia sloboda, rovnost' a spravodlivost' (Kis 2019).

Spravodlivost' ako jedna zo základných hodnôt pluralistickej demokratickej spoločnosti hl'adá odpoved' na otázku, či dávat' lud'om určité statky podl'a ich zásluh alebo podla ich postavenia $v$ spoločenskej hierarchii (Samu 2008). O miere spravodlivosti však $v$ demokratickej spoločnosti môže rozhodovat' iba nezávislá a nestranná inštitúcia, ktorá musí rozhodovat' podla práva. Takúto inštitúciu tvorí v každom štáte iba systém súdnej moci, pričom rozhodnutia súdu sa považujú za objektívne spravodlivé, a teda pre všetky strany záväzné (Kis 2019). Sociálna (rozdel'ovacia) spravodlivost' musí vychádzat' z faktu, že neexistuje objektívne kritérium na jej presné posúdenie. Najmä chudobné vrstvy požadujú od štátu, aby prerozdel'ovaním cez štátny rozpočet hmotne zabezpečil tých, ktorí pomoc potrebujú. Hlavným argumentom pre sociálnu spravodlivost' je udržanie spoločenského poriadku, aby ludia pod hranicou chudoby revoltou nedestabilizovali daný spoločenský poriadok. Sociálna spravodlivost' je vlastne vzt’ahom medzi jedincom (indivíduom) a štátnou mocou v spoločnosti, a to $v$ súlade so zákonom a bez porušenia prirodzených práv jedinca. Sociálna spravodlivost' je nedosiahnutel'ný ideál, ku ktorému sa možno približovat' prostredníctvom snahy vytvorit' stav, ked' materiálne postavenie člena spoločnosti zodpovedá jeho vynaloženému úsiliu. Niektorí ju chápu ako ideálnu tendenciu usporiadania spoločnosti, ktorá zabezpečuje, že rast 
blahobytu bohatých je sprevádzaný rastom dôchodkov a príjmov chudobných (Huoranszki 1998).

\section{Politické ideológie a $\mathbf{k}$ nim prislúchajúce typy wefare state}

Neoddelitel'nou súčast'ou sociálnej politiky západnej civilizácie je problematika welfare state. Je to prirodzené, pretože základným subjektom sociálnej politiky je štát. Bez ohladu na to, aké označenie dostáva, môžeme konštatovat', že bej jeho priamej účasti, ktorá je legislatívne zakotvená, by sociálna politika v súčasnom svete nebola myslitel'ná. $Z$ dôvodu častých nejasností spojených s prekladom tohto pojmu sa používa $v$ anglickej podobe. Najčastejšie sa pojem welfare state používa ako synonymum pojmu štát sociálneho blahobytu (Geffert 2014).

Ako je možné rozhodnút' sa $v$ otázke, ktorý distribučný systém považujeme za spravodlivý? Ako dokážeme posúdit', aké obmedzenie individuálnej slobody považujeme za legitímne? Aj ked' teoreticky by bolo možné vytvorit' samostatné stanovisko ku každej otázke, väčšina ludí má na výber pripravené teórie. $Z$ takýchto komplexných teórií, ktoré z osobitostí ludskej povahy slúžia na účel politického združovania, a ponúka viac či menej ucelený systém názorov a prostriedkov na dosiahnutie ciela. Tieto teórie predstavujú politické ideológie ako prepojenie normatívnych filozofických teórií a pragmatických politických nástrojov. Rozsah a povaha zásahu štátu do sociálnej politiky do vel'kej miery ovplyvňuje ideológia, ktorú uprednostňujú tí, ktorí sú pri moci, a sociálne skupiny za nimi; samozrejme, okrem iných faktorov, ktoré ovplyvňujú sociálnu politiku štátu. Medzi tri najdôležitejšie politické ideológie ovplyvňujúce západnú civilizáciu sú liberalizmus, konzervativizmus a socializmus. Zoskupovanie sociálnych politík podla ideológií samozrejme nie je absolútne, pretože sociálne politiky jednotlivých štátov nie sú ovplyvňované iba ideológiou, ale na druhej strane existuje vel'a rozdielov medzi sociálnymi politikami krajín s rovnakou ideológiou. Esping-Andersenova typológia rozlišuje medzi týmito tromi ideologickými prúdmi liberálnymi, konzervatívnymi a sociálnodemokratickými systémami blahobytu, typológiou sociálnych štátov (Esping-Andersen 1990).

Zástancovia liberalizmu, ktorí veria v trhovú ekonomiku veria, že trh odmeňuje každého na základe jeho zásluh, čím vytvára rovnaké podmienky pre všetkých. Predstavitelia liberalizmu zastávajú názor, v ktorom pre dosiahnutie sociálnej spravodlivosti postačujú pravidlá prvky trhového mechanizmu (Qakeshott 2001). Reziduálny, liberálny model welfare state núti aktérov k prijímaniu vlastnej zodpovednosti a len tí, ktorí v tejto oblasti zlyhajú, môžu očakávat' minimálnu mieru poskytnutej pomoci, a to len v prípade, že dokladujú jej potrebnost'. Sociálna opora tu nemá preventívny charakter a nemá podobu práva na sociálne zaistenie. Liberálny sociálny štát je zo svojej povahy zvyškový ako do rozsahu solidarity, tak do jej 
zaistenia. Sociálne riziká sú vymedzené vel'mi úzko a pomoc nastupuje až vtedy, ked' všetky ostatné prostriedky zlyhajú (Geffert 2007).

Naopak teoretický zástancovia hodnoty socializmu pochybujú o sociálnej spravodlivosti trhového mechanizmu. Prvky ako štastie, pôvod, spoločenské postavenie sú $v$ tomto systéme príliš dôležité, takže nevedú k sociálnej spravodlivosti. Sociálna spravodlivost' úzko súvisí so sociálnou rovnostou, ktorú chápu v zmysle prekonania vel'kých sociálnych rozdielov, ktoré spôsobujú otváranie nožníc sociálnej diferenciácie. Je budovaná na štátnom prerozdelovaní toho, čo už raz extrémne nespravodlivo rozdelil trh, ktorý sa riadi čisto ekonomickými preferenciami (Qakeshott 2001). Sociálnodemokratický, redistributívny model welfare state je založený na univerzalizme, čo znamená, že všetci občania sú zaopatrení proti sociálnym rizikám nezávisle na prijmoch. Miera zaopatrenia je najvyššia medzi všetkými typmi welfare state. Štát je zodpovedný za blahobyt všetkých občanov. Vo financovaní a poskytovaní sociálnej starostlivosti jednoznačne dominuje štát, existuje široká siet' služieb starostlivosti (Geffert 2007).

Štát v konzervativizme sa môže usilovat' o zniženie sociálnych nerovností iba vtedy, ak je to v medziach spravodlivosti (Bayer 2003). V konzervativizme prevláda všeobecný názor, podla ktorého nerovnost' sama o sebe nepredstavuje nespravodlivost'. Zásahy štátu sú odôvodnené v prípade legislatívneho rámca. Majetková nerovnost' je podla konzervativizmu zakódovaná $v$ rozdieloch medzi l'ud'mi, ako aj v štastí a náhodách, ktoré majú rozhodujúci vplyv na l'udskej výkonnosti. Oddelenie týchto momentov od osobných zásluh, výkonu tých, ktorí pracujú, je beznádejný záväzok, takže ocenit' skutočnú hodnotu ludskej činnosti je úplne mimo intelektuálnu schopnost' človeka. (Cecil 1912). Konzervatívny, kontinentálny model welfare state sa historicky vyvinul z ochrany kvalifikovaných robotníkov a zamestnancov, ktorých status dosiahnutý vlastným pracovným výkonom sa snaží zabezpečit pred výkyvmi trhovej ekonomiky. Hlavným nástrojom tejto ochrany je povinné členstvo tých, ktorí pracujú, v systéme sociálneho poistenia, ktorý je založený na profesijnom základe. Primárne zásahy štátu sú až na poslednom mieste, dochádza knim až vtedy, ak systém úplne zlyhá. Konzervatívny sa nazýva preto, lebo oproti egalitárnym systémom konzervuje rozdiely v statuse medzi jednotlivými profesiami a odbormi činnosti (Geffert 2007).

Spravodlivost' nie je založená iba na distribučných zásadách (pravidlá spravodlivosti), ale aj na iných aspektoch týkajúcich sa distribúcie. Örkény uvádza tieto aspekty (Örkény 1997): Povaha tovaru (dobier), ktorý sa má distribuovat', podla jeho množstva a kvality. Kto má kontrolu nad distribúciou a kto má iba podiel na nich alebo ktoré osoby môžu byt' vylúčený z tohto procesu. Aké hodnoty a zásady sa uplatňujú pri definovaní distribučnej spravodlivosti (napríklad užitočnost' a zásluhy, potreba a rovnost'). Aj ked'spoločnost'ou uznané zásady a hodnoty sú chápané ako spravodlivé, vzniká nespravodlivost', pretože samotné konanie bolo priamo alebo nepriamo nespravodlivé. Samotný typ postupu, účast' účastníkov na 
rozhodovacom procese alebo prístup $\mathrm{k}$ informáciám a použitie a interpretácia informácií počas procesu môžu byt' nespravodlivé. $\vee$ tomto prípade hovoríme o procesnej spravodlivosti alebo dokonca o nespravodlivosti.) Zásady spravodlivosti sa zvyčajne vyznačujú nasledujúcimi úvahami: rozlišujú medzi zásadami zásluh, užitočnosti, výkonnosti a prínosu od zásad spravodlivého rozdelenia a rozdelenia podla potrieb. Rozlišovat' podla toho, či je rozhodovací proces konsenzuálny; či postup vyplýva zo skutočného rozhodnutia účastníkov výmenného aktu; a či je alebo nie je dodržané pravidlo predpísané v postupe. Či sa pravidlá vztahujú na skutočné, domnelé alebo požadované sociálne vzt'ahy.

\section{Záver}

Hlavným ciel'om príspevku bolo analyzovanie skúmania sociálnej spravodlivosti vybranými spoločenskovednými disciplínami vpriestore západnej civilizácie. Chápanie skúmaného fenoménu je podmienené základnými piliermi západnej civilizácie. Základné systémy, ktoré vymedzujú západnú civilizáciu sú systémový prístup a hodnotový odkaz starovekého Grécka, krest'anské sociálne učenie, moderné a postmoderné politické ideológie. Sociálnu spravodlivost' možno vnímat' ako činnost' alebo pojem, ktorý je charakteristický značným hodnotovým relativizmom. Nemožno unifikovat' a absolutizovat' jeho podobu, chápanie a používanie, napriek tomu je nevyhnutné vždy istým spôsobom reflektovat' jeho uplatňovanie $v$ praktickom živote a rešpektovat' vymedzenie $v$ morálnych alebo právnych normách. Existuje široké spektrum aplikácie sociálnej spravodlivosti v živote človeka, jednotlivých sociálnych skupín, ale aj spoločnosti ako celku. Sociálna spravodlivost' predstavuje sociálnu hodnotu, ktorá sa často zužuje na spravodlivé prerozdelenie dobier, príležitostí, prostriedkov zabezpečenia medzi jednotlivcov užšej skupiny alebo v rámci celej spoločnosti. Otázka sociálnej spravodlivosti nie je obmedzená len na individuálne hladisko, pretože hodnota sociálnej spravodlivosti je relevantná takmer vo všetkých oblastiach sociálnych vzt’ahov a inštitúcií. Sociálnu spravodlivost' vnímame cez naše súdy, t.j. podla našich hodnôt a aktuálneho subjektívneho spoločenského postavenia posudzujeme jednotlivé myšlienky, spoločenské konania, ktoré vyhlasujeme za sociálne spravodlivé.

\section{Pod'akovanie}

Tento článok je súčast'ou projektu VEGA 1/0290/20 - Sociálna spravodlivost' a starobné dôchodkové sporenie $v$ Slovenskej republike.

\section{Literatúra}

ANDORKA, R. 1997.Bevezetés a szociológiába. Budapest: Osiris.. 785p. ISBN 963-389-848$X$ 
ANDORKA, R. 2003.Bevezetés a szociológiába. Budapest: Osiris.. 662p. ISBN 963-389-4026

ANGELUSZ, R. 2004. A társadalmi rétegződés komponensei: válogatott tanulmányok. Budapest: Ú-M-K. 360p. ISBN 963-949-454-2

BAYER, J. 2001. A polotiaki gondolkodás története: bevezetés. Budapest: Osiris. 420p. ISBN 963-379-303-3

BAYER, J. 2003. A politiaki gondolkodás trténete: bevezetés. Budapest: Osiris, 420p. ISBN 963-389-436-0

BIHARI, M., POKOL, B. 2009. POLITOLÓGIA. Budapest: Nemzeti Tankönyvkiádó. 648p. ISBN 978-963-1967-85-2

BODAI, Zs. 2001. A pénz filozófiiája: Válogatás. Budapest: Aula. 190p. ISBN 963-907-869-7

CECIL, H. 1912. Conservativism. London: Williams and Norgate

DEANE, P.,SZEPESI, Gy. 1997. A közgazdasági gondolatok fejlődése. Budapest: Aula. 262p. ISBN 963-907-833-6

ESPRING ANDERSEN, G. 1990. The Three Worlds of Welfare Capitalism. Cambidge: Polity Press

FÖLDESI, T. 1983. Az igazságosság dilemmái. Budapest: Kossuth. 303p. ISBN 963-092-1700

GEFFERT, R. 2007. Empirická analýza preferencií hodnôt politicko-ideologických paradigiem ako predikátorov rozhodovania sa vo vol'bách. In: Sociálne a politické analýzy. Roč. 1, č.1, s. 136-237 [cit. 9. septembra 2020]. ISSN 324-5555

GEFFERT, R. 2014. Sociálna politika a jej axiologické orientácie .Košice: UPJŠ v Košiciach. 1. vydanie. $160 \mathrm{~s}$. ISBN 978-80-8152-099-0

HART, H.L.A. et al. 1995. A jog fogalma. Budapest: Osiris. 375p. ISBN 963-379-074-3

HUORANSZKI, F. 1998. Modern politikai filozófia. Budapest: Osiris. 198p. ISBN 963-379-2681

KIS, J. 2000. Alkotmányos demokrácia: három tanulmány. Budapest: INDOK. 279p. ISBN 963004-297-5

KIS, J. 2019. Alkotmányos demokrácia: régebbi és újabb közelítések. Budapest: Kalligram. 571p. ISBN 978-963-4681-06-9

KONEČNÝ, S. 2019. Monism of justice and dualism of socialjustice in social policy. In: Ljetopis socijalnog rada. Vol. 26, No. 3, 419-445 pp [cit. 10. septembra 2020]. ISSN 1848-7971

KONEČNÝ, S.2019. Ekonomické nástroje v teórii verejnej politiky. In: Verejná správa a spoločnost'. Ročník XX, Číslo 1/2019, 61-84 pp [cit. 10. septembra 2020] ISSN 2453-9236

LUDASSY, M. 1989. Szabadság, Egyenlőség, Igazságosság. Budapest: Magvető. 213p. ISBN 963-141-527-9 
MÁTYÁS, A. 2004. A korai közgazdaságtan története. Budapest: Aula. 132p. ISBN 963-958527-0

MCLANEY, E.J. 1994. Business Finance for Decision Makers. 2nd ed. London: Pitman Publishing, ISBN 0-273-60421-X.

MELLÁR, T. 2015. Szemben az árral - Rendhagyó közgazdasági előadások. Budapest: Akadémiai Kiadó. 332p. ISBN 978-963-05-9607-7

ÖRKÉNY, A. 1997. Hétköznapok igazsága: igazságossági felfogások egy nemzetközi összehasonlitás tükrében. Budapest: Új Mandátum Kiadó. 293p. ISBN 963-747-658-X

PACZOLAY, P. 1996. Apolitikatudomány kialakulása - A politikaelmélet története az ókortól a huszadik századig. Budapest: Korona. 266p. ISBN 963-903-614-5

POKOL, B. 1991. A jog szerkezete. Budapest: Felsőoktatási Koordinációs Iroda. 202p. ISBN 963-767-066

QAKESHOTT, M. 2001. Politikai racionalizmus. Budapest: Új Mandátum Könyvkiadó. 532p. ISBN 963-9336-13-0

SAMU, M. 2008. Jogpolitika. Budapest: Akadémiai Kiadó. 336p. ISBN 978-963-0586-33-7

VISEGRÁDY, A. 2001. A jog - és állambölcselet alapjai. Budapest: Dialóg Campus. 256p. ISBN 963-912-394-3

VOEGELIN, E. 2014. Új politikatudomány. Budapest: Nemzeti Közszolgálati Egyetem Molnár Tamás Kutató Központ. 146p. ISBN 978-615-549-183-2

\author{
Adresa autora \\ Mgr. Oskár Tóth \\ Interný doktorand \\ Univerzita Pavla Jozefa Šafárika v Košiciach \\ Fakulta verejnej správy \\ Katedra verejnej politiky a teórie verejnej správy \\ Popradská 66, 04011 Košice \\ E-mail: oskar.toth@student.upjs.sk
}

